\title{
Integrating Nuclear Energy to Oilfield Operations - Two Case Studies
}

\section{Canadian Unconventional Resources Conference}

The INL is a

U.S. Department of Energy

National Laboratory

operated by

Battelle Energy Alliance

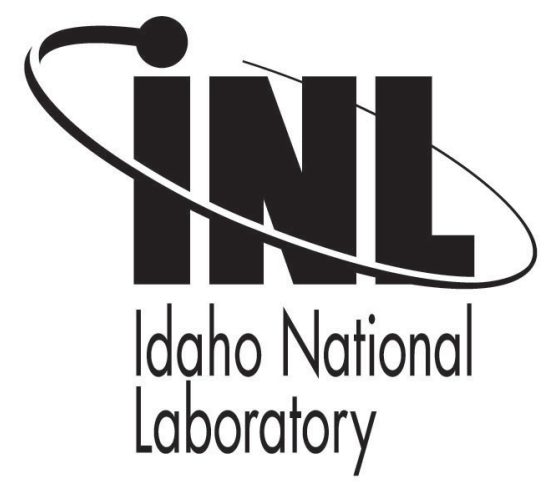

Eric P. Robertson

Lee O. Nelson

Michael G. McKellar

Anastasia Gandrik

Mike Patterson

\section{November 2011}

This is a preprint of a paper intended for publication in a journal or proceedings. Since changes may be made before publication, this preprint should not be cited or reproduced without permission of the author. This document was prepared as an account of work sponsored by an agency of the United States Government. Neither the United States Government nor any agency thereof, or any of their employees, makes any warranty, expressed or implied, or assumes any legal liability or responsibility for any third party's use, or the results of such use, of any information, apparatus, product or process disclosed in this report, or represents that its use by such third party would not infringe privately owned rights. The views expressed in this paper are not necessarily those of the United States Government or the sponsoring agency. 

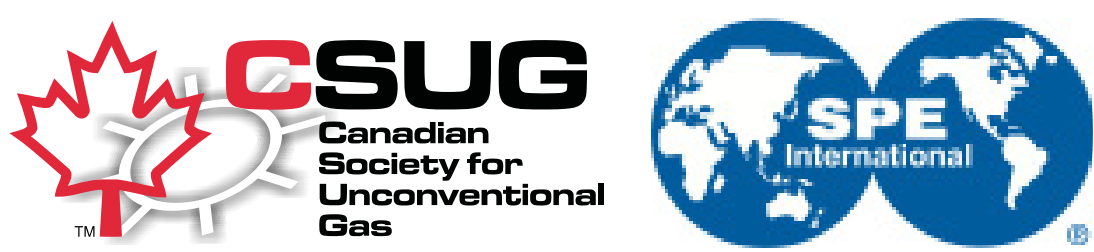

\title{
CSUG/SPE 146587
}

\section{Integrating Nuclear Energy to Oilfield Operations -- Two Case Studies}

Eric P. Robertson, Lee O. Nelson, Michael G. McKellar, Anastasia Gandrik, and Mike Patterson, Idaho National Laboratory

\begin{abstract}
Fossil fuel resources that require large energy inputs for extraction, such as the Canadian oil sands and the Green River oil shale resource in the western USA, could benefit from the use of nuclear power instead of power generated by natural gas combustion. This paper discusses the technical and economic aspects of integrating nuclear energy with oil sands operations and the development of oil shale resources. A high temperature gas-cooled reactor (HTGR) that produces heat in the form of high pressure steam (no electricity production) was selected as the nuclear power source for both fossil fuel resources. Both cases were based on 50,000 bbl/day output. The oil sands case was a steam-assisted, gravity-drainage (SAGD) operation located in the Canadian oil sands belt. The oil shale development was an in-situ oil shale retorting operation located in western Colorado, USA. The technical feasibility of the integrating nuclear power was assessed. Preliminary economic analyses of each case were evaluated using a discounted cash flow, rate of return approach.

Integrating an HTGR to both the SAGD oil sands operation and the oil shale development was found to be technically feasible for both cases. In the oil sands case, integrating an $\mathrm{HTGR}$ eliminated natural gas combustion and associated $\mathrm{CO}_{2}$ emissions, although there were still some emissions associated with imported electrical power. In the in situ oil shale case, integrating an HTGR reduced $\mathrm{CO}_{2}$ emissions by $88 \%$ and increased natural gas production by over $400 \%$. Economic analyses included parametric evaluations on taxes imposed on $\mathrm{CO}_{2}$ emissions, royalty rates, capital costs, etc. The magnitude of the tax on $\mathrm{CO}_{2}$ emissions was found to have a major impact on the economic results of the cases considered.

As the world moves toward limiting $\mathrm{CO}_{2}$ emissions, integrating non- $\mathrm{CO}_{2}$-emitting energy sources to the development of energy-intense fossil fuel resources is becoming increasingly important. This paper attempts to reduce the barriers that have traditionally separated fossil fuel development and application of nuclear power and to promote serious discussion of ideas about hybrid energy systems.

\section{Introduction}

This paper addresses potential integration opportunities for single or multiple High Temperature Gas-cooled Reactor (HTGR) modules with production of oil from oil shale using an in situ retort process. It has been prepared as part of a study for the Next Generation Nuclear Plant (NGNP) Project to evaluate the integration of HTGR technology with conventional chemical processes. The NGNP Project functions under U.S. Department of Energy (DOE) direction to meet a national strategic need identified in the Energy Policy Act of 2005 to promote reliance on safe, clean, economic nuclear energy and to establish a greenhouse-gas-free technology for the production of hydrogen. The NGNP represents an integration of high-temperature reactor technology with advanced hydrogen, electricity, and process heat production capabilities, thereby meeting the mission need identified by DOE. The strategic goal of the NGNP Project is to broaden the environmental and economic benefits of nuclear energy in the U.S. economy by demonstrating its applicability to market sectors not being served by light water reactors.
\end{abstract}

\section{High Temperature Gas-Cooled Nuclear Reactor Background}

An HTGR module produces process heat (steam or high-temperature helium), electricity, and/or hydrogen. An HTGR outlet temperature of $750^{\circ} \mathrm{C}$ for the primary fluid loop is assumed for this study, which reflects the initial HTGR design and assumes a conservative outlet temperature; temperatures of $950^{\circ} \mathrm{C}$ are anticipated for advanced HTGR designs. The output from a single HTGR module is assumed to be $600 \mathrm{MWth}$. A $25^{\circ} \mathrm{C}$ temperature approach is also assumed for the heat exchanger between the primary and secondary fluid loops. 
In conventional chemical processes, process heat, electricity, and hydrogen are generated by the combustion of fossil fuels such as coal and natural gas, resulting in significant emissions of greenhouse gases such as carbon dioxide $\left(\mathrm{CO}_{2}\right)$. An HTGR could produce and supply these products to conventional chemical processes without generating any greenhouse gases. The use of an HTGR to supply process heat, electricity, or hydrogen to conventional processes is referred to as an HTGR-integrated process.

\section{Oil Shale Background}

The process of heating oil shale in an anoxic environment to pyrolyze the kerogen embedded within the oil shale and produce oil and gas is commonly called retorting. Kerogen is the organic portion of oil shale and is largely insoluble in organic solvents because of its very large molecular structure. If buried at sufficient depth, time, and concentration, kerogen will release oil and gas; however, kerogen-rich oil shale deposits have not been buried at sufficient depths for oil and gas to form naturally. Retorting the oil shale is a method to convert the kerogen to oil and gas.

Shallow oil shale deposits may be mined and processed in a surface, or ex situ, retort. Deeper oil shale deposits may be retorted in situ by conveying heat into the subsurface and producing the resulting oil and gas in a manner similar to conventional oil and gas production. The oil resource within the Green River Formation oil shale deposits in Colorado, Utah, and Wyoming is over 3 trillion barrels (Johnson et al. 2010a; Johnson et al. 2010b; Bartis et al. 2005). The total recoverable oil from this resource is estimated to be about 1.4 trillion barrels (Bartis et al. 2005), which is greater than the 1.1 trillion barrels of total historical world oil production (BP 2010). Comparing these historical and potential oil recoveries shows that the oil shale recoverable resource is very, very large and once commercial oil production from oil shale is demonstrated, it will likely continue for many decades and perhaps centuries due to the huge quantity of the resource.

The basis for this economic evaluation is an in situ oil shale production project producing 50,000 bbl/day of shale oil, the product being ready for transport via pipeline to an area refinery. This analysis assumes that refining capacity exists in the region to accept the shale oil produced from the operation.

There are no commercial scale in situ oil shale operations anywhere in the world at this time. However, field-scale research, development, and demonstration projects are currently operating in western Colorado and eastern Utah. A largescale, commercial in situ oil shale industry in the United States may emerge within the next 10 to 15 years. Even though there are no commercial in situ oil shale operations, numerous reports and analyses have been written and performed from which to draw the parameters necessary to perform an analysis of a hypothetical in situ oil shale production operation and its integration with an HTGR. Development and deployment of a commercial HTGR may also require 10 to 15 years. Thus, this conceptual study of integrating an HTGR with an in situ oil operation is timely.

Shale oil is produced from oil shale by pyrolyzing the kerogen molecules within the oil shale to generate oil, gas, and char. The mass balance for oil and gas generation for an in situ oil shale retort was done by balancing the carbon and hydrogen atoms in the parent molecule (kerogen) with the carbon and hydrogen atoms in the product molecules (char, oil, and gas). The mass balance of the generated products per mass of kerogen is listed in Table 1.

\section{Table 1. Kerogen pyrolysis mass} balance for an in situ retort.

\begin{tabular}{|lc|}
\hline Product & $\begin{array}{c}\text { Calculated } \\
\text { Value (g/g kerogen) }\end{array}$ \\
\hline Char & 0.286 \\
Gas & 0.196 \\
Shale oil & 0.518 \\
Total of products & 1.000 \\
\hline
\end{tabular}

The produced char is a solid that is left in place within the oil shale retort zone, while the oil and gas are mobile and able to flow through the subsurface to production wells. The shale oil is high quality oil with a gravity of $40^{\circ} \mathrm{API}$. The produced gas has a heat content of about $1770 \mathrm{Btu} / \mathrm{scf}$. Assuming an average grade (Fischer Assay) of the oil shale of $25.2 \mathrm{gal} /$ ton for the oil shale, the values in Table 1 translate into the generation of 20 gal of shale oil, 652 scf of hydrocarbon gas, and $76 \mathrm{lbm}$ of char per ton of raw oil shale.

\section{SAGD Background}

A schematic diagram of a conventional SAGD operation is shown in Figure 1. The operation consists of a SAGD well pair; the top horizontal well is used to supply steam and the lower horizontal well is used to collect the heavy oil product. The wells run parallel to each other. The top and bottom wells are located 50 to 200 meters below the surface, are separated by approximately five meters, and are up to 1,000 meters in length. The injected steam travels along the upper perforated-well bore and heats the oil sand deposits in the vicinity of the upper well. After the deposit is heated, the bitumen becomes fluid and drains to the lower perforated-well where it is pumped and collected along with water condensed from the injected steam. The bitumen/water mixture is then sent through a fairly complicated water/oil separation system consisting of standard API separators, hydro cyclone separators, and in some cases, air flotation devices. Up to $85 \%$ of the water can be recovered and recycled back to the steam generator after it is sufficiently treated. The recovered bitumen is then mixed with a diluent, assumed to be naphtha, to provide fluidity for conventional pipeline transport to an upgrading facility.

The models were sized to produce 56,000 barrels per day of pure bitumen product. Again, naphtha is blended with the pure bitumen to produce dilbit, i.e., diluted bitumen. The project was sized based on the amount of bitumen that could be recovered through the integration of a single HTGR unit for dedicated steam generation. The integration point of the HTGR is steam production only; the minimal amount of power required for the SAGD process is assumed to be purchased from the grid in order to minimize HTGR cost by eliminating equipment associated with power production from the HTGR. Thermal 
parasitic losses for the heat exchangers required for the nuclear-integrated option are accounted for in the model as well as heat losses from the long-distance, high-temperature steam piping.

\section{Integration of Nuclear Heat}

Although an HTGR is capable of delivering heat, electricity, or hydrogen, its capability of delivering heat in the form of high temperature and pressure steam is of most use to the two oilfield operations (in situ oil shale retorting and oil production from SAGD) evaluated in this paper. Upgrading the oil sands bitumen using hydrogen, heat, and electricity from a nuclear power plant has been evaluated (Wood 2011), but is not included in this paper.

\section{Oil Shale and Nuclear Heat}

Steam was selected as the working fluid in the secondary heat transfer loop after analysis of other fluids, namely helium and nitrogen. An HTGR module(s) is assumed to be physically located near the oil shale operation such that the heat lost during surface transport of the heating fluid is negligible. Using electricity (as opposed to utilizing the HTGR heat directly) from an HTGR for heat generation via electric heaters is possible, but converting heat to electricity and then back to heat is an inefficient process and has high energy losses. The closed-loop production design in was selected as the base case for HTGR integration because it has the capacity to directly utilize and recycle the heat output from an HTGR.

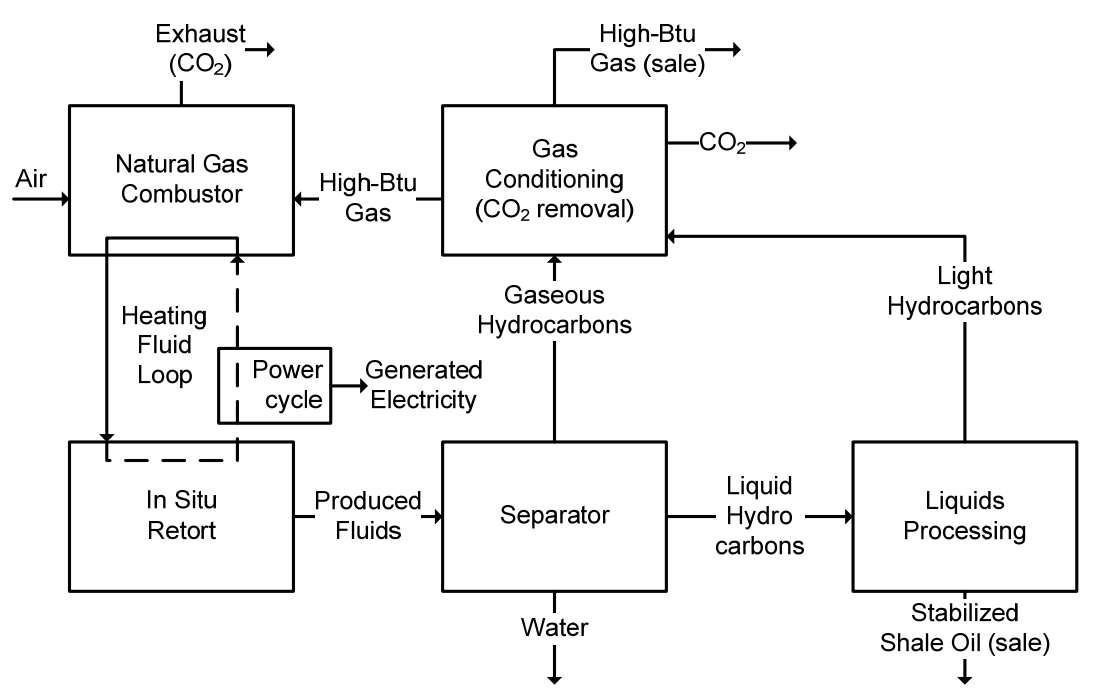

Figure 1. Simplified block flow diagram of a conventional process for recovery ofl gas and oil from an in situ oil shale retort process.

A conventional in situ retort process was selected for evaluation, shown as a simplified block flow diagram in Figure 1. Steam is generated in a boiler fired by natural gas. A closed-loop injection-andreturn piping system recirculates the steam from the boiler to the subsurface and back. In the subsurface, the heat from the circulating steam is transferred by conduction through the pipe wall into the oil shale. As the shale heats, the kerogen is converted to natural gas and shale oil, which are transported to the surface by the pressure generated during the conversion through production wells. A portion of the produced natural gas is used to generate steam in the gas-fired boiler. The $\mathrm{CO}_{2}$ that is generated in the process is released to the atmosphere.

The model for an integrated process using heat from a nuclear reactor to replace the heat derived from natural gas combustion is identical to the conventional process except an HTGR and a heat exchanger replace the gas combuster/steam boiler.

A summary of the mass and energy balance results for the conventional and HTGR-integrated cases is shown in Figure 2. Both processes generate $50,000 \mathrm{bbl}$ of oil per day. The conventional process produces less natural gas, but more electricity than the HTGR-integrated process and emits approximately 12.4 times more $\mathrm{CO}_{2}$. 

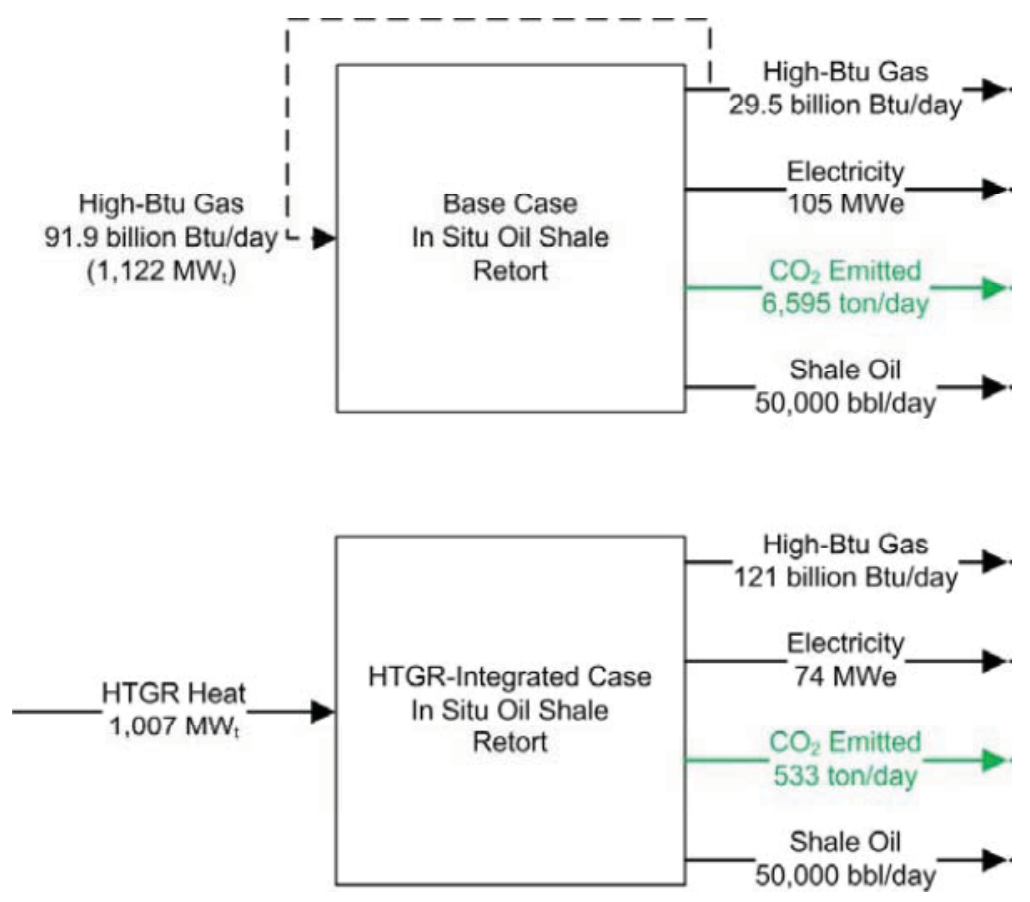

Figure 2. Simplified net mass and energy inputs and outputs for two in situ oil shale retort cases.

\section{SAGD and Nuclear Heat}

The conventional SAGD block flow diagram is presented in Figure 3. Steam used for recovery of the bitumen is generated in a steam boiler with heat from the combustion of natural gas. The model for a process integrated with heat from an HTGR is identical to the conventional process except the steam boiler uses heat generated in a HTGR. The HTGR is assumed to be located within 20 kilometers of several SAGD well pairs in order to provide continuous heat and steam to the SAGD operation. A separate study in conjunction with this work concluded that $1 \%$ of the heat duty of the steam is lost per kilometer transported (AREVA 2008).

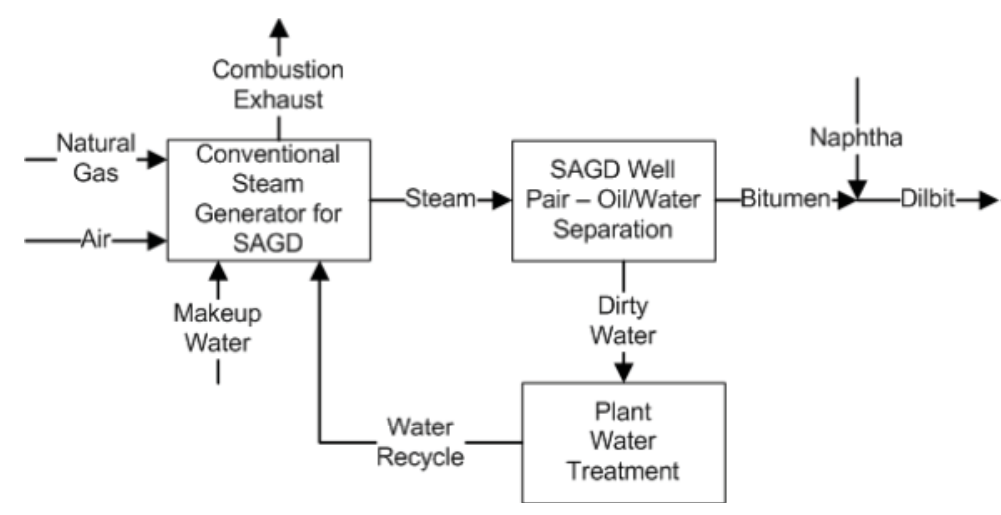

Figure 3. Simplified block flow diagram of a conventional SAGD oil recovery process.
Analysis of the conventional SAGD case indicates a strong potential heat integration opportunity for a HTGR. In the conventional case, $100 \%$ of the natural gas feed to the process is burned to provide heat for steam generation. The operating conditions for the steam are saturated steam at $310^{\circ} \mathrm{C}$ (Finan 2010), which can alternatively be supplied by the $540^{\circ} \mathrm{C}$ steam from the HTGR via an intermediate heat exchanger. Steam is supplied to the well pad via insulated piping to minimize heat loss between the HTGR and the well pads.

The process modeling results for the nuclearintegrated SAGD case look technically promising. A single $600 \mathrm{MWt}$ HTGR would be required to produce 56,000 barrels per day of bitumen. As mentioned previously, it was assumed that the reactor would supply only heat to the fossil process; the minimal amount of power required for the SAGD process is assumed to be purchased from the grid in order to minimize HTGR cost by eliminating equipment associated with power production from the HTGR. By substituting nuclear heat for natural gas combustion in the steam generator, natural gas consumption is eliminated from the process. Power consumption for the plant does increase from 6.9 MW for the conventional case to 16.9 MW for the nuclear-integrated case. The primary factor for increased power consumption is the increased power load required to operate miscellaneous equipment in the $\mathrm{HTGR}$. $\mathrm{CO}_{2}$ emissions are also eliminated from the process, although there are still $\mathrm{CO}_{2}$ emissions from imported power. A summary of the modeling results for the two cases is presented graphically in Figure 4. The conventional SAGD case serves as a basis for comparison with the nuclear-integrated case. 

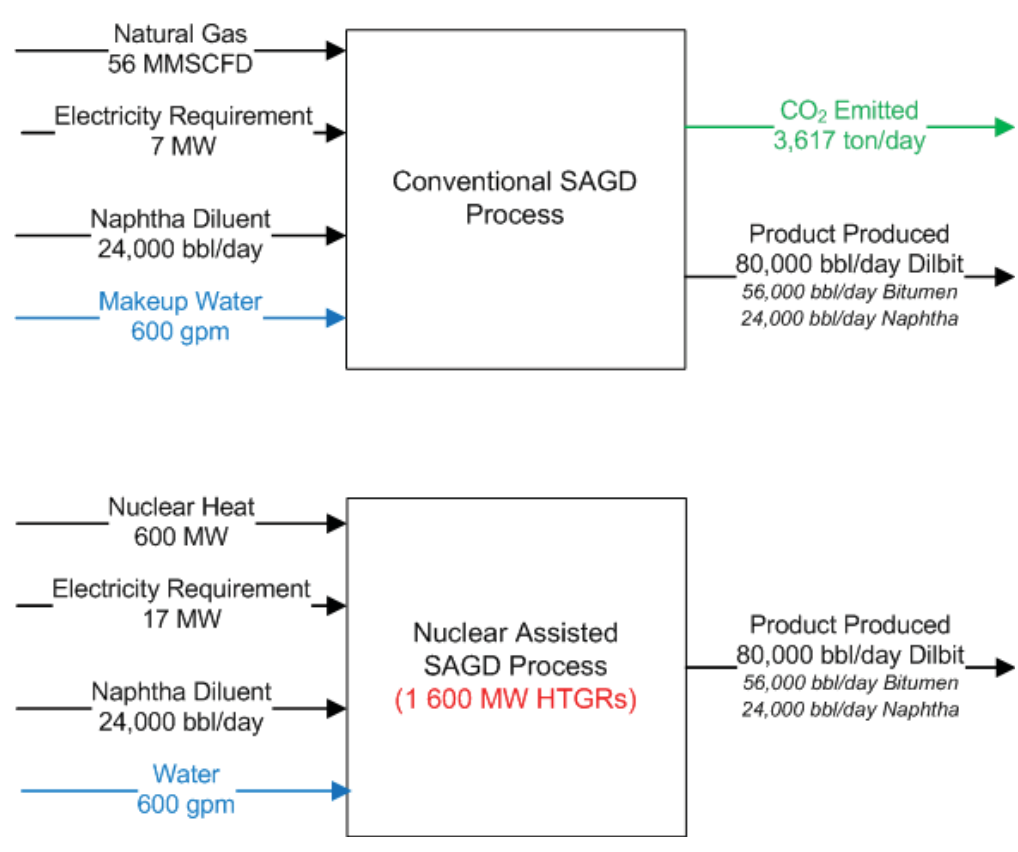

Figure 4. Simplified net mass and energy inputs and outputs for two SAGD production cases

\section{Economic Results}

Economic models were developed for the conventional and HTGR-integrated process models to assess the economic viability of HTGR integration. The economic models reflect all-in costs and revenues, and allow an after-tax discounted cash flow analysis based on the estimated total capital investment (TCI). Capital cost estimates meet the requirements established by the Association for Advancement of Cost Engineering International Class 4, which has an expected accuracy range of $30 \%$ to $+50 \%$. Manufacturing costs are the sum of direct production costs (raw materials, utilities, operating labor, and maintenance) and indirect costs (plant overhead, insurance, and taxes). Selling prices for products were calculated based on a $12 \%$ internal rate of return (IRR) on the equity investment.

\begin{tabular}{|ll|}
\hline $\begin{array}{l}\text { Table 2. General ass umptions used for the } \\
\text { economic analyses. }\end{array}$ \\
\hline Economic parameter & Value \\
\hline Plant economic life & 30 years (excludes construction time) \\
Construction period & $\begin{array}{l}\text { Fossil portion: three years } \\
\text { HTGR plant: three years }\end{array}$ \\
Start-up assumptions & Operating costs: 120\% of steady-state \\
& Revenues: $65 \%$ of steady-state \\
Plant availability & $90 \%$ \\
Discount rate & $12 \%$ \\
Inflation rate & $3 \%$ \\
Interest rate on debt & $8 \%$ \\
Repayment term & 15 years \\
Tax basis assumptions & Effective income tax rate: $38 \%$ \\
Depreciation & 15 -year MACRS \\
\hline
\end{tabular}

Economic viability was determined by comparing the production costs from HTGR-integrated processes with production costs from conventional processes. To understand the impact of fluctuating natural gas prices, selling prices were calculated based on low, average, and high natural gas prices during the past 6 years. This report summarizes the results for average ( $\$ 5.50$ or $\$ 6.50 / \mathrm{MSCF}$ ) natural gas prices. The general assumptions for the economic models are shown in Table 2.

The economic analyses, as summarized in this report, are based on a simplified business model in which a single entity owns and operates the industrial and associated HTGR plants. Economic sensitivity analyses were conducted to assess the comparative viability of the evaluated conventional and HTGRintegrated processes. The results are summarized as sensitivity charts. These were created by varying the values of a selected economic parameter, while holding all other economic parameters at their baseline value, then measuring the effect on the final production cost.

\section{In Situ Oil Shale Economics}

Figure 5 shows the sensitivity plots for both in situ oil shale retorting cases. These plots were created by varying each input variable independent of the others and measuring the effect on project economics (required oil price). The minimum, most likely, and maximum values for each input variable are listed in Table 4.

The project discount rate was determined to have the greatest affect on project economics for the Base Case, followed closely by the tax on $\mathrm{CO}_{2}$ emissions, well drilling and completion costs, and natural gas price forecast. Although other input variables had some impact, the majority of the uncertainty in project economics for this case was accounted for in these three critical variables. 
For the HTGR Case, the project discount rate had the greatest affect on project economics followed by the natural gas price forecast, total capital investment of the surface facilities (including the HTGR), well drilling and completion costs, and debt to equity ratio. As with the Base Case, other input variables had a lesser impact on the HTGR Case economic outcome.

Economic input variable, default value

Project discount rate, $12 \%$

CO2 emissions tax, 60 \$/ton

Well drilling \& completion costs, $\%$ of default

Natural gas price, $5.50 \$ / M M B t u$

Debt to equity ratio, 0.5 dimensionless

Surface facilities capital costs, \% of default

Electricity sale price, $0.0988 \$ / \mathrm{kw}$-hr

Initial royalty rate, $5 \%$

Debt repayment term, $15 \mathrm{yr}$

Debt interest rate, $8 \%$

Fed tax rate, $35 \%$

Well financing duration, $2 \mathrm{yr}$

Maximum royalty rate, $12.5 \%$

Lease cost, 5000 \$/ac

Well O\&M costs, 1000 \$/well/mo

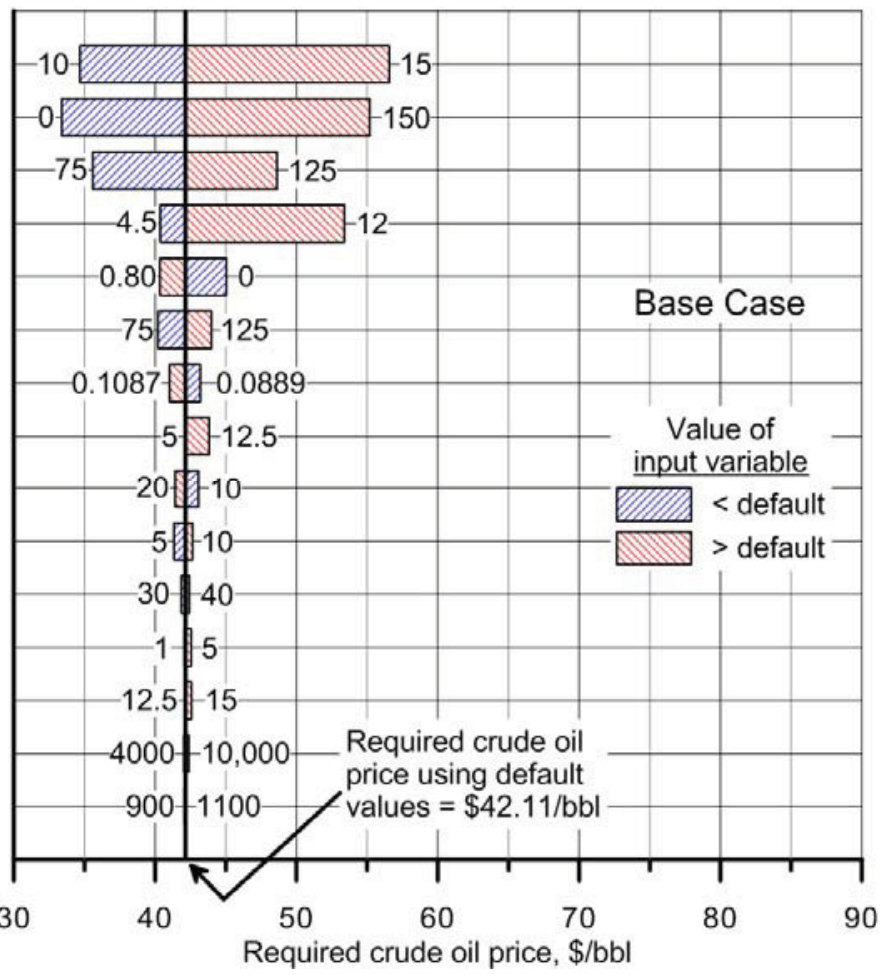

Required crude oil price, $\$ / \mathrm{bbl}$

Economic input variable, default value

Project discount rate, $12 \%$

Natural gas price, 5.50 \$/MMBtu

Surface facilities capital costs, $\%$ of default

Well drilling \& completion costs, \% of default

Debt to equity ratio, 0.5 dimensionless

Debt repayment term, $15 \mathrm{yr}$

Debt interest rate, $8 \%$

Initial royalty rate, $5 \%$

Fed tax rate, $35 \%$

CO2 emissions tax, 60 \$/ton

Electricity sale price, $0.0988 \$ / \mathrm{kw}$-hr

Maximum royalty rate, $12.5 \%$

Well financing duration, $2 \mathrm{yr}$

Lease cost, $5000 \$ / a c$

Well O\&M costs, 1000 \$/well/mo

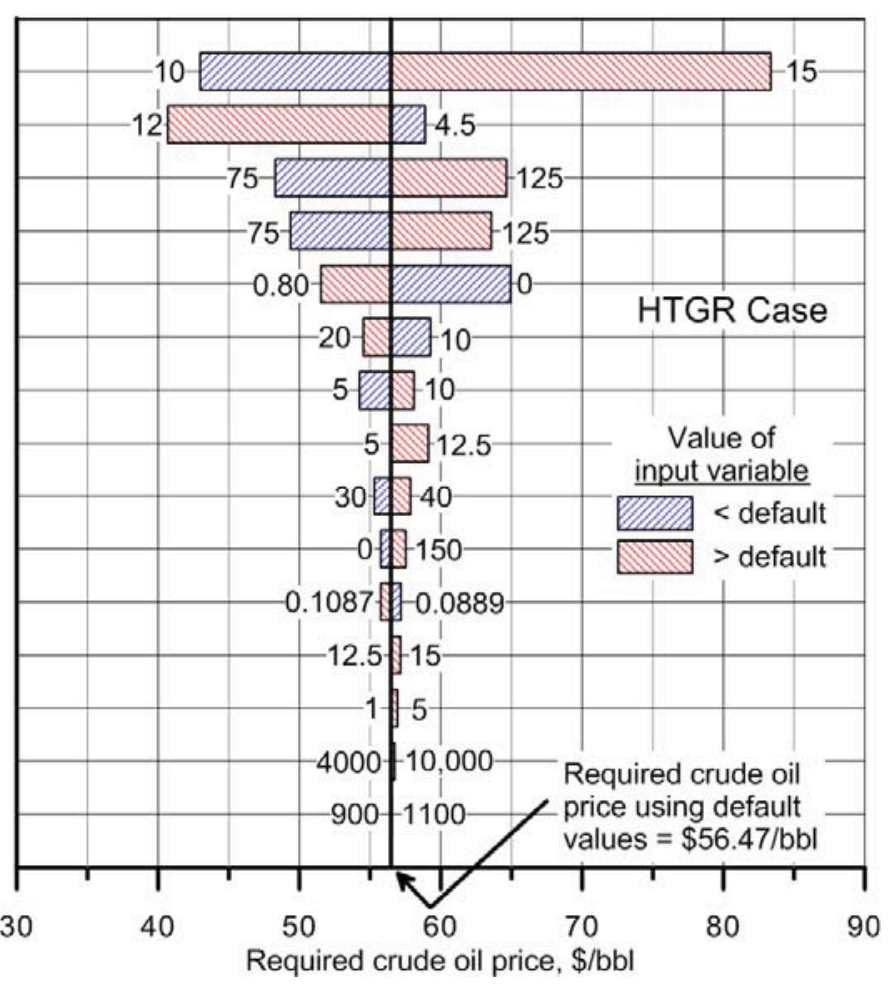

Figure 5. Sensitivity charts for the Base Case (upper figure) and the HTGR Case (lower figure) showing the relative impact of each input variable on project economics. 


\section{SAGD Economics}

The nuclear-integrated SAGD option provides economic stability with respect to fluctuations in natural gas prices. Though the IRR is lower at all but the lowest crude selling price, it is still significantly above $12 \%$ for crude prices above $\$ 40 / \mathrm{bbl}$, indicating a sizable return on investment (Figure 6). However, even with high natural gas prices, the traditional SAGD process economically outperforms the nuclear-integrated option. With a reduction in the HTGR cost by $30 \%$, the nuclearintegrated option economically outperforms the traditional option when natural gas prices exceed $\$ 10.50 / \mathrm{MSCF}$.

Figure 6 depicts the associated IRR results for the SAGD cases for the baseline TCI of the HTGR and low, average, and high natural gas prices. Figure 7 presents the necessary selling price of crude for a $12 \%$ IRR as a function of natural gas price.

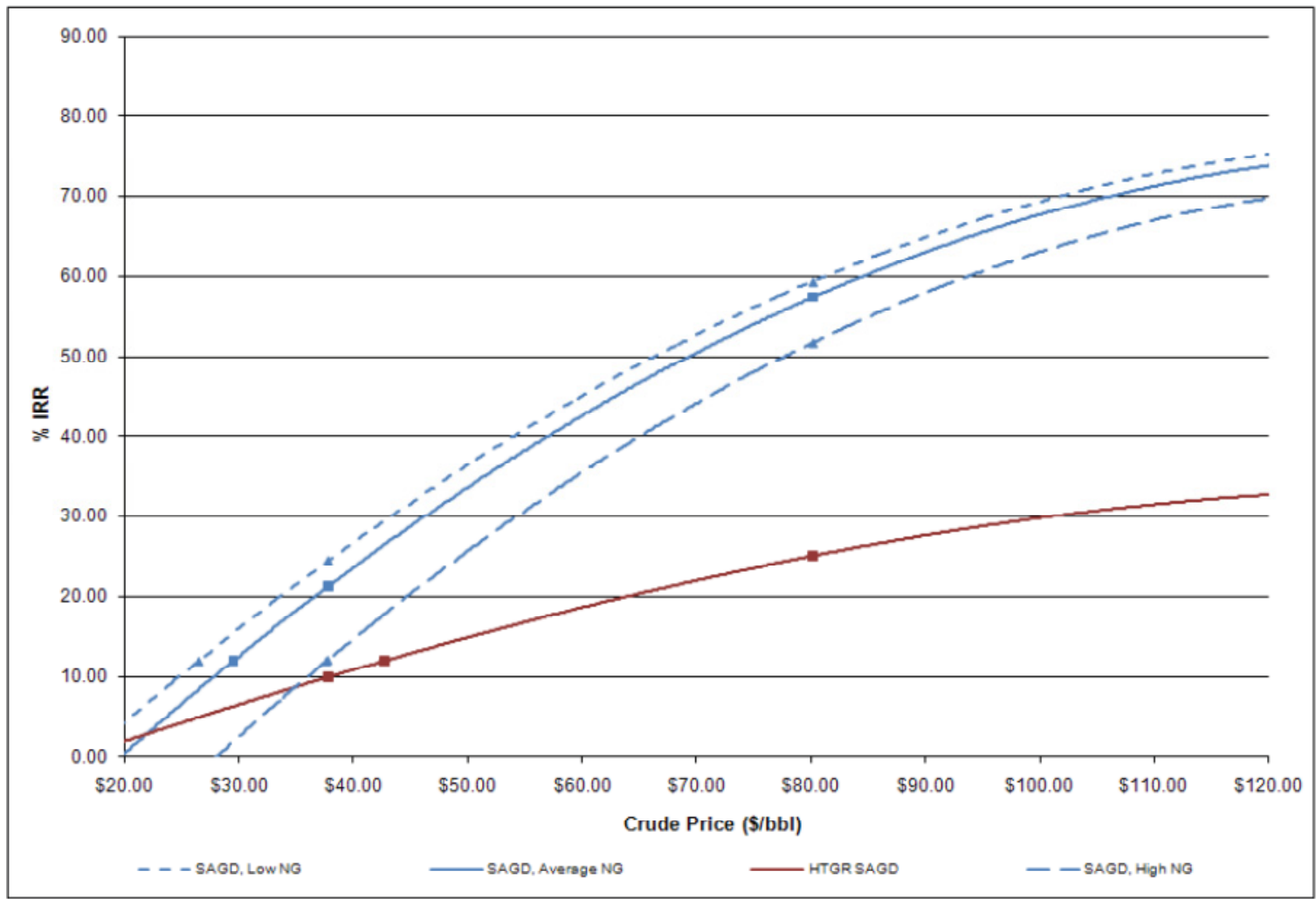

Figure 6. Conventional and HTGR-integrated SAGD economic results. 


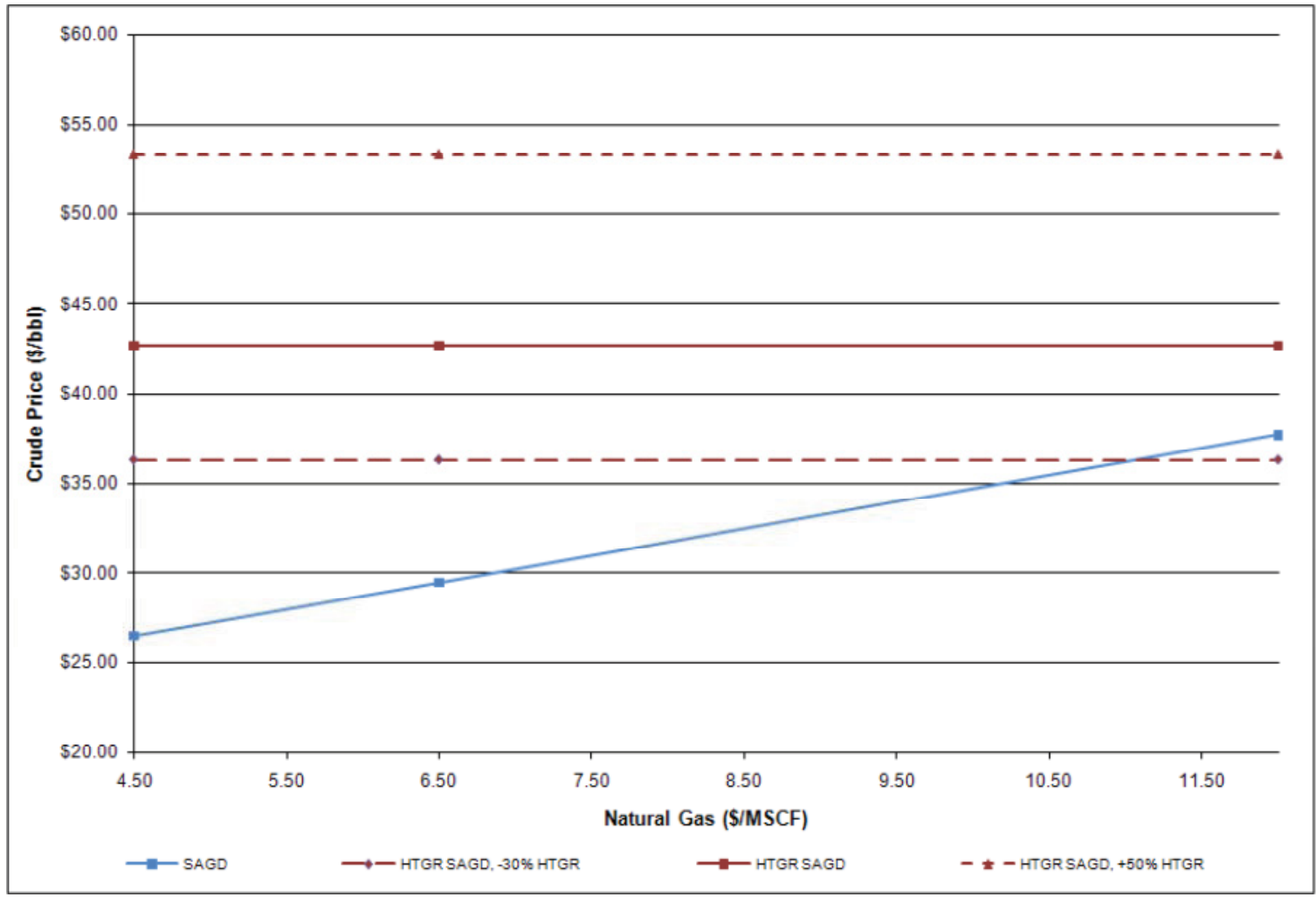

Figure 7. Conventional and nuclear SAGD, crude price as a function of natural gas price and a $12 \%$ IRR

From these figures, it is apparent that the nuclear-integrated SAGD option provides economic stability with respect to fluctuations in natural gas prices. Though the IRR is lower at all but the lowest crude selling price, it is still significantly above $12 \%$ for crude prices above $\$ 40 / \mathrm{bbl}$, indicating a sizable return on investment (Figure 7 ). However, even with high natural gas prices, the traditional SAGD process economically outperforms the nuclear-integrated option. With a reduction in the HTGR cost by $30 \%$, the nuclear-integrated option economically outperforms the traditional option when natural gas prices exceed \$10.50/MSCF (Figure 7).

The carbon tax results show that the nuclear integrated SAGD case only outperforms the conventional SAGD case at a $12 \%$ IRR when the carbon tax is over $\$ 100 /$ ton $\mathrm{CO}_{2}$ for the baseline HTGR cost, when HTGR cost is reduced by $30 \%$ a $\mathrm{CO}_{2}$ tax of only $\$ 50 /$ ton is required. If a carbon tax of $\$ 100 /$ ton $\mathrm{CO}_{2}$ is imposed, the nuclear-integrated case will outperform the conventional case when natural gas prices are over $\$ 6.50 / \mathrm{MSCF}$, as shown in Figure 8. 


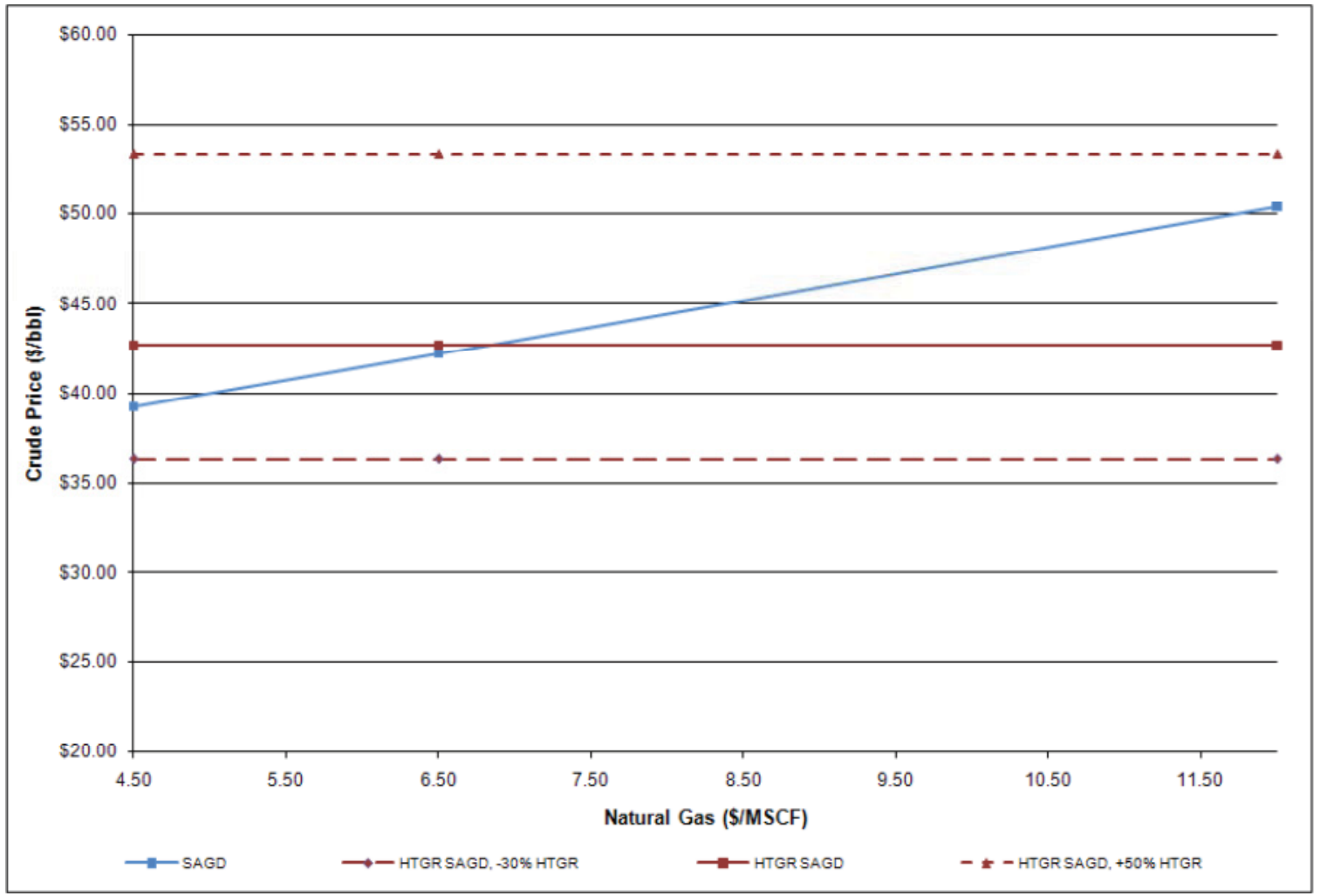

Figure 8. Conventional and nuclear SAGD, crude price as a function of natural gas price with a $\$ 100 /$ ton CO2 tax and a $12 \%$ IRR.

\section{Conclusions}

Oil shale:

- High-Btu hydrocarbon gas is produced in each case during the pyrolysis of the kerogen in the oil shale. Over $75 \%$ of the produced gas in the base case is used to generate the heat needed for the retort process; while in the HTGR-integrated case, the full gas stream is available for sale.

- $\mathrm{CO}_{2}$ is produced from both cases as well, but the base case produces more than 12 times more $\mathrm{CO}_{2}$ than the HTGR-integrated cases, which may become an important economic and environmental issue if future $\mathrm{CO}_{2}$ emissions are restricted either by governmental controls or through penalties.

- In both cases, excess electricity is generated and can be sold as revenue. The base case produces $42 \%$ more electricity than the HTGR-integrated case.

- The heat put into the system for the HTGR-integrated case (1007 MW) is less than the heat input for the base case (1122 MW).

- The energy return on investment (EROI) for the base case is 4.44, while the EROI for the HTGR-integrated case is 4.80. These EROI values do not include the energy required to capture, compress, and sequester any generated $\mathrm{CO}_{2}$.

- High average temperatures of the heater pipe through the retort zone result in excessive energy losses due to temperature and pressure constraints on the pump circulating the steam and water through the retort zone.

- After 60 years of oil production from an in situ retort operation, the retorted zone would expand to just over 4000 subsurface acres or 6.4 square miles. If an HTGR were to be located in the center of the $6.4 \mathrm{mi} 2$, the distance from the HTGR to the furthest point of the retort zone would be 1.8 miles. Transporting heat this distance is not expected to be of concern. If the retort zone thickness were greater than the assumed $235 \mathrm{ft}$, the horizontal area of the zone could potentially be much smaller.

- For both cases, the analysis identified the heat transfer ratio as the most critical input parameter for this case, followed by the recoverable fraction of the generated oil and gas, the composition of the kerogen in the oil shale, the mass of FA oil to kerogen ratio, and the FA grade of the oil shale. Refining the estimates and narrowing the potential distribution of these critical variables through further research would reduce the variability and uncertainty associated with the outcome of these cases.

Economically, both the Base Case and the HTGR Case show positive economic results with the Base Case possessing a higher IRR using the most likely input variables.

- $\mathrm{CO}_{2}$ emissions were identified as a major economic driver for the Base Case, but were negligible for the HTGR Case.

- Capital costs and product prices were major economic drivers for both Cases considered. 
- $\quad$ Both Cases were very sensitive to the project discount rate assumed for the analyses.

\section{SAGD:}

- A single $600 \mathrm{MWt}$ HTGR would be required to produce 56,000 barrels per day of bitumen

- By substituting nuclear heat for natural gas combustion in the steam generator, natural gas consumption is eliminated from the process

- $\mathrm{CO}_{2}$ emissions from the plant are also eliminated completely by integrating a high-temperature nuclear reactor into the flowsheet, as natural gas is no longer combusted, although there would still be emissions associated with imported power.

Economically, the nuclear-integrated SAGD option provides economic stability with respect to fluctuations in natural gas prices:

- Though the IRR is lower for all crude prices considered, it is still above $12 \%$ when crude selling prices exceed $\$ 40 / \mathrm{bbl}$, indicating a sizable return on investment

- The required selling price of crude to achieve a $12 \%$ IRR for the nuclear-integrated case is about one and a half times the selling price required for the conventional SAGD case for an HTGR capital cost of $\$ 2,000 / \mathrm{kWt}$, $\$ 43 / \mathrm{bbl}$ versus $\$ 30 / \mathrm{bbl}$ for conventional SAGD at average natural gas prices

- When the HTGR capital cost is decreased by $30 \%$, the nuclear-integrated selling price of crude is still greater than the price required in the conventional case, $\$ 36 / \mathrm{bbl}$ versus $\$ 30 / \mathrm{bbl}$ for conventional SAGD at average natural gas prices

- In a carbon-constrained scenario where $\mathrm{CO}_{2}$ emissions are taxed, a $\mathrm{CO}_{2}$ tax of greater than $\$ 100 /$ ton- $\mathrm{CO}$ would be needed to equate the economics of the nuclear-integrated SAGD case with the conventional SAGD case, at a HTGR capital cost of $\$ 2,000 / \mathrm{kWt}$ and an average natural gas price

- The necessary $\mathrm{CO}_{2}$ tax decreases to $\$ 50 /$ ton $\mathrm{CO}_{2}$ when the capital cost of the HTGR is decreased by $30 \%$

- If a carbon tax of $\$ 100 /$ ton $\mathrm{CO}_{2}$ is imposed, the nuclear-integrated SAGD process economically outperforms the conventional SAGD process for natural gas prices above $\$ 6.50 / \mathrm{MSCF}$.

\section{Acknowledgments}

The authors would like to thank Rick Wood for his contributions to the content of the paper and management at Idaho National Laboratory (Phil Mills) for permission to publish this work which was supported by the Idaho National Laboratory and by the U.S. Department of Energy, Office of Nuclear Energy, Next Generation Nuclear Plant program.

\section{References}

AREVA, 2008, NGNP with Hydrogen Production Conceptual Design Studies Power Conversion Study, 12-0904881-001.

Bartis, J. T., T. LaTourrette, L. Dixon, D. J. Peterson, and G. Cecchine, 2005, Oil Shale Development in the United States, Prepared by Rand Corporation for the National Energy Technology Laboratory of the U.S. Department of Energy.

BP, 2010, "Statistical Review of World Energy 2010," published on-line at: http://www.bp.com/productlanding.do?categoryId= 6929\& contentId=7044622.

Finan, Ashley, and Andrew Kadak, 2010, "Integration with Nuclear Energy with Oil Sands Projects for Reduced Green House Gases Emissions and Natural Gas Consumption Into Oil Sands Projects," Journal of Engineering for Gas Turbines and Power, Vol. 132, pp. 1-8.

Johnson, R.C., T.J. Mercier, M.E. Brownfield, and J.G. Self, 2010a, "Assessment of in-place oil shale resources in the Eocene Green River Formation, Uinta Basin, Utah and Colorado," U.S. Geological Survey Digital Data Series DDS-69-BB, Chapter 1.

Johnson, R.C., T.J. Mercier, M.E. Brownfield, M.P. Pantea, and J.G. Self, 2010b, "An Assessment of In-Place Oil Shale Resources in the Green River Formation, Piceance Basin, Colorado," US Geological Survey Oil Shale Assessment Team, Chapter 1, U.S. Geological Survey Digital Data Series DDS-69-Y.

Wood, R.A., 2011, “HTGR-Integrated Bitumen Upgrading Analysis,” Idaho National Laboratory, TEV-1147, April. 